\title{
The Effect Of Job Characteristics On Job Satisfaction And Its Impact On Employee Performance
}

\author{
Sugianto \\ Departement of Business Administration Padjadjaran University, \\ Bandung, Indonesia \\ Bambang Hermanto \\ Departement of Business Administration Padjadjaran University, \\ Bandung, Indonesia \\ Herwan Abdul Muhyi \\ Departement of Business Administration Padjadjaran University, \\ Bandung, Indonesia \\ Margo Purnomo \\ Departement of Business Administration Padjadjaran University, \\ Bandung, Indonesia
}

\begin{abstract}
Research the effect of job characteristics on job satisfaction and its impact on employee performance highlights the influence of job characteristics on job satisfaction and whether it has an influence on employee performance by taking the location of research on cooperatives in Solo, Central Java. Cooperatives face several problems, namely high levels of employee turnover. This study uses quantitative methods using a descriptive approach. For data collection the method used is by giving questionnaires to employees and interviews with informants who then analyzed the data using smart PLS. Based on the results of the study found that job characteristics have a positive but not significant relationship to employee performance, the next job characteristics have a positive and significant relationship to job satisfaction and the last job satisfaction has a positive and significant relationship to employee performance.
\end{abstract}

Keywords: Job Characteristics, Job Satisfaction, Employee Performance

\section{INTRODUCTION}

According to Robbins (2007) job characteristics are one of the factors that can affect employee performance. Job characteristics determine the suitability of a person with a particular field of work and enable a person to be more successful in the field of his work. Hackman and Oldham (1980) job characteristics have five factors: variety skills, task identity, task significance , autonomy and feedback.

Nimalathasan (2009) employee job satisfaction is related to employee expectations of superiors, co-workers and the work itself. Luthans (2006) states that there are five factors that affect job satisfaction, namely income, co-workers, opportunities to develop, the work itself, and the supervisor. According to Simamora (2004) Employee performance is something that influences how much they contribute to the organization. According to Simamora (2004) there are several factors that affect performance, among others: personal characteristics, job descriptions, the purpose of performance evaluation, and the attitudes of workers. 
Based on the results of preliminary interviews with employees at the Solo City Cooperative, there is a tendency that employees do the same job, are simple, and tend to be repetitive. This condition will obviously cause a sense of boredom. In addition there are also indications that the cooperative management does not fully give freedom to its employees to handle complex and varied tasks, so that employees cannot demonstrate initiative and independence in completing their work. Based on information from the Cooperative Supervisory Board of Solo City Riyadi, the cooperative turnover of employees is still very high, especially for staff level positions because the salary received by cooperative employees is still very far compared to the Solo City regional minimum wage.

Table 1

Cooperative employee turnover rate at Slamet Riyadi University Solo

\begin{tabular}{|c|c|c|c|c|c|c|}
\hline \multirow{2}{*}{ Years } & \multicolumn{6}{|c|}{ Job Level } \\
\cline { 2 - 7 } & \multicolumn{3}{|c|}{ Manager } & \multicolumn{3}{c|}{ Staff } \\
\cline { 2 - 7 } & In & Out & Percentage & In & Out & Percentage \\
\hline 2013 & 2 & 1 & $50 \%$ & 5 & 15 & $33 \%$ \\
\hline 2014 & 2 & 3 & $67 \%$ & 5 & 10 & $50 \%$ \\
\hline 2015 & 2 & 2 & $50 \%$ & 3 & 17 & $18 \%$ \\
\hline 2016 & 3 & 2 & $67 \%$ & 10 & 15 & $67 \%$ \\
\hline
\end{tabular}

Source : Riyadi Solo City Cooperative

The low job satisfaction can certainly have a negative impact, such as suspended cooperatives, slow completion of work and high turnover of employees. Even though cooperatives with more satisfied employees tend to be more effective than cooperatives with unsatisfied employees. Therefore, the company is important to pay attention to and maintain the level of employee satisfaction to get the best employee performance.

\section{RESEARCH METHODS}

This study uses a human resource management science approach. This study was designed with the aim of analyzing the relationships between variables. The design of this study includes correlational research, namely research conducted with the intention of analyzing the relationships between variables. The variables used are job characteristics, job satisfaction, and employee performance with an approach using quantitative methods.

Quantitative research is an approach for testing the relationships among variables. These variables, in turn, can be measured, typically on instruments, numbered data can be analyzed using statistical procedures (Creswell, 2014). Collecting data obtained from this study is by observing, recording and collecting various information and data found in the field through case studies and surveys. To collect various information needed in this case, the questionnaire used in the direct visit to the research location at the Solo City Cooperative.

\section{RESULTS AND DISCUSSION}

Analysis of the description of the data taken for this study is a questionnaire given to employees of the Solo City Cooperative with a total of 55 samples are as follows: 
Table 2

Description of Research Variables

\begin{tabular}{|l|c|c|c|c|c|}
\hline & N & Minimum & Maximum & Mean & $\begin{array}{c}\text { Std. } \\
\text { Deviation }\end{array}$ \\
\hline $\begin{array}{l}\text { Job } \\
\text { Characteristics }\end{array}$ & 55 & 1 & 5 & 0.77020 & 0.19875 \\
\hline Job Satisfaction & 55 & 1 & 5 & 0.06356 & 0.02539 \\
\hline $\begin{array}{l}\text { Employee } \\
\text { Performance }\end{array}$ & 55 & 1 & 5 & $\begin{array}{c}0.68396 \\
1\end{array}$ & 0.19340 \\
\hline
\end{tabular}

Source : results of data processing

Based on the table above it can be seen that during the observation period the job characteristics variable shows an average value of 0.77020 with a standard deviation of 0.19875 so that the standard deviation is smaller than the average. This indicates that the average distribution of data will be the respondent's answer to the good variable. Job satisfaction has an average value of 0.06356 and a standard deviation of 0.02539 so that the standard deviation is smaller than the average. This indicates that the average distribution of respondents' answers to the variables is good. Based on the above table it can be seen that during the observation period the performance variable shows an average value of 0.683961 with a standard deviation of 0.19340 so that the standard deviation is smaller than the average. This indicates that the average distribution of data will be the respondent's answer to the good variable.

There are three criteria in using data analysis techniques with SmartPLS to assess the outer model, namely Convergent Validity, Discriminant Validity and Composite Reliability (Ghozali,2008). Convergent validity of the measurement model with reflexive indicators was assessed based on the correlation between the item score / component score estimated by PLS software. Individual reflexive measures are said to be high if they correlate more than 0.70 with the construct measured.

Table 3

Outer Loadings (Measurement Model)

\begin{tabular}{|c|c|c|c|}
\hline Matrix & $\begin{array}{c}\text { Employee } \\
\text { Performance }\end{array}$ & $\begin{array}{c}\text { Job } \\
\text { Characteristics }\end{array}$ & $\begin{array}{c}\text { Job } \\
\text { Satisfaction }\end{array}$ \\
\hline X1.1 & & 0.857 & \\
\hline X1.2 & & 0.869 & \\
\hline X1.3 & & 0.761 & \\
\hline X1.4 & & 0.746 & \\
\hline X1.5 & & 0.791 & \\
\hline X2.1 & & & 0.815 \\
\hline X2.2 & & & 0.718 \\
\hline X2.3 & & & 0.791 \\
\hline X2.4 & & & 0.780 \\
\hline Matrix & Employee & Job & $\begin{array}{c}\text { Job } \\
\text { Performance }\end{array}$ \\
\hline Characteristics & Satisfaction \\
\hline Y1.1 & 0.828 & & \\
\hline Y1.3 & 0.860 & & \\
\hline
\end{tabular}

Source : results of data processing 
The results of processing with smartPLS can be seen in table 3 shows that all loading factors have values above 0.70 , so that the construct for all variables is no longer eliminated from the model.

Furthermore, it is calculated that the value of Discriminant Validity. Discriminant validity is done to ensure that each concept of each latent variable is different from other variables. The model has good discriminant validity if each loading value of each indicator of a latent variable has the largest loading value with other loading values against other latent variables. The discriminant validity test results are obtained as follows:

Table 4

Nilai Discriminat Validity

(Cross Loading)

\begin{tabular}{|l|c|c|c|}
\hline & $\begin{array}{c}\text { Employee } \\
\text { Performance }\end{array}$ & $\begin{array}{c}\text { Job } \\
\text { Characteristics }\end{array}$ & $\begin{array}{c}\text { Job } \\
\text { Satisfaction }\end{array}$ \\
\hline X1.1 & 0.495 & 0.857 & 0.661 \\
\hline X1.2 & 0.466 & 0.869 & 0.598 \\
\hline X1.3 & 0.525 & 0.761 & 0.513 \\
\hline X1.4 & 0.512 & 0.746 & 0.641 \\
\hline X1.5 & 0.439 & 0.791 & 0.677 \\
\hline X2.1 & 0.508 & 0.803 & 0.815 \\
\hline X2.2 & 0.559 & 0.567 & 0.718 \\
\hline X2.3 & 0.666 & 0.514 & 0.791 \\
\hline X2.4 & 0.585 & 0.477 & 0.780 \\
\hline Y1.1 & 0.828 & 0.514 & 0.614 \\
\hline Y1.2 & 0.860 & 0.502 & 0.691 \\
\hline Y1.3 & 0.775 & 0.477 & 0.507 \\
\hline
\end{tabular}

Source : results of data processing

From table 4 it can be seen that several loading factor values for each indicator of each latent variable have a loading factor value which is the most large compared to the loading value if it is associated with other latent variables. This means that each latent variable has good discriminant validity where some latent variables still have a gauge that is highly correlated with other constructs.

Criteria for validity and reliability can also be seen from the reliability value of a construct and the value of Average Variance Extracted (AVE) from each construct. The construct is said to have high reliability if the value is 0.70 and AVE is above 0.50 (Creswell,2014). In table 4 , the values of Composite Reliability and AVE will be presented for all variables.

Table 5

Composite Reliability dan Average Variance Extracted

\begin{tabular}{|l|c|c|}
\hline & $\begin{array}{c}\text { Composite } \\
\text { Reliability }\end{array}$ & $\begin{array}{c}\text { Average Variance } \\
\text { Extracted }\end{array}$ \\
\hline Employee Performance & 0.862 & 0.675 \\
\hline Job Characteristics & 0.903 & 0.650 \\
\hline Job Satisfaction & 0.859 & 0.603 \\
\hline
\end{tabular}

Source : results of data processing 
Based on table 5 it can be concluded that all constructs meet reliable criteria. This is indicated by the composite reliability value above 0.70 and Average variance extracted above 0.50 as recommended criteria. In assessing the model with PLS begins by looking at R-square for each dependent latent variable. Table 6 is the result of R-square estimation using SmartPLS.

Table 6

R-Square Point

\begin{tabular}{|l|l|}
\hline Var & R-Square \\
\hline Job Characteristics & \\
\hline Job Satisfaction & 0.555 \\
\hline Employee Performance & 0.594 \\
\hline
\end{tabular}

Source : results of data processing

Table 6 shows the R-square value for the variable job satisfaction obtained at 0.555 , for the performance variable obtained is 0.594 . These results indicate that $55.5 \%$ of the variables of job satisfaction can be influenced by the variables of job characteristics and $59.4 \%$ of performance variables can affect job characteristics and performance.

Figure 1

Structural Model

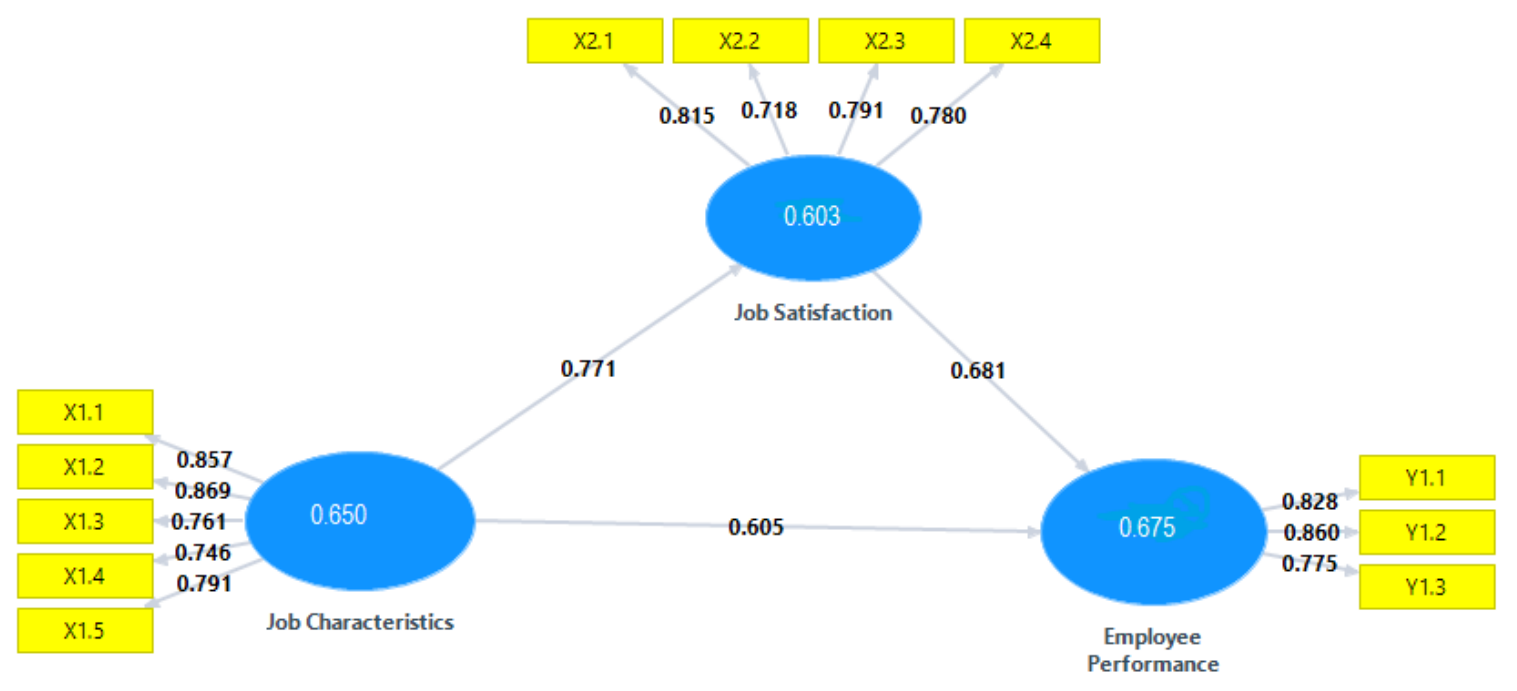

Source : results of data processing

CONCLUSION

1. The results of testing the first hypothesis shows that the relationship between job characteristics and employee performance shows a path coefficient of 0.080 with a t value of 0.427 . this value is smaller than t table $(1,960)$. This result means that job characteristics have a positive but not significant relationship to employee performance which means that it is not in accordance with the first hypothesis where job characteristics have an impact on employee performance directly. This means that Hypothesis 1 is rejected, thus indicating that job characteristics do not have a significant direct influence on employee performance. The reason for rejecting this hypothesis is because cooperative employees feel that they have accepted the existing conditions. This is strengthened based on interviews with employees and Unsiri Savings and Loans 
Cooperative Manager who stated that employees were accustomed to doing various jobs, so employees did not need to develop their skills.

2. The results of testing the second hypothesis shows that the relationship between job characteristics and job satisfaction variables shows a path coefficient of 0.771 with a $t$ value of 11.634 . this value is greater than $t$ table $(1,960)$. This result means that job characteristics have a positive and significant relationship to job satisfaction which means that it is in accordance with the second hypothesis where the characteristics of work encourage job satisfaction. This means that Hypothesis 2 is accepted so that the job characteristics (occupational mastery) owned by employees are high. This is due to the high awareness of employees in doing the work that is charged to them so that the work is done in a structured manner giving rewards and bonuses given by cooperatives to employees very well, besides that employees work with mutual respect in carrying out their duties.

3. The results of testing the third hypothesis shows that the relationship of job satisfaction variables with employee performance shows a path coefficient of 0.681 with a t value of 3.482. this value is greater than t table $(1,960)$. This result means that job satisfaction has a positive and significant relationship to employee performance which is meaningful in accordance with the third hypothesis where job satisfaction has an impact on employee performance. This means that Hypothesis 3 is accepted so that the higher the job satisfaction that employees receive, the higher the performance of their employees. Conversely, employees who feel dissatisfied in their work tend to have thoughts of not being serious and evaluating alternative work, and are eager to get out of the current work location because they hope to find a more satisfying job. Performance is closely related to the level of worker satisfaction and one of these factors is the satisfaction of supervision carried out by the leadership. Satisfaction with the leader will be explored, if the supervision is carried out in accordance with work procedures, discipline and sanctions for employees who do not have good work performance.

\section{Reference}

Anthony, Scott, Gravelle Hugh, Steven Simoens,Chris Bojke and Bonnie Sibbald. 2006. Job Satisfaction and Quitting Intentions: A Structural Model of British General Practitioners. British Journal of Industrial Relations. Vol. 44, No. 3, 09.2006, p. 519-540

Antoncic, J. A., \& Antoncic, B. 2011. Employee Satisfaction, Intrapreneurship and Firm Growth: A Model. Industrial Management and Data Systems, Vol. 111(4), pp. 589-607. ISSN 0263-5577

Bakhshi, A. Kumar K., Rani E., 2009. Organizational Justice Perceptions As Predictor Of Job Satisfaction And Organization Commitment. International Journal Of Business And Management, Vol. 4, No 9, pp. 145-154.

Brown Steven, \& Tobias Huning. 2010. Intrinsic Motivation and Job Satisfaction : The Intervening Role Of Goal Orientation. Allied Academies International Conference.Vol 15 No 1 ISSN 1948-3155

Cecilia, Engko. 2008. Pengaruh Kepuasan Kerja terhadap Kinerja Individual Dengan Self Efficacy sebagai variabel intervening. Jurnal Bisnis dan Akuntansi. Vol 10 No 1 April 2008, pp 1-12

Creswell, J. W. 2014. Research Design: Qualitative, Quantitative and Mixed Methods Approaches, 4 Edition. London: Sage

Emin, Kahya. 2007. The effect of job characterics and working condition on job performance. International journal of industrial egronomics. Vol 37 issue 6 pages 515-523

Gavrea, Corina, Liviu Ilies, Roxana Stegerean. 2011. Determinants of Organizational Performance: The case of romania. Management and Marketing Challenges for the knowledge society. Vol 6 No 2 pp 285-300

Ghozali, I., 2008. Structural Equation Modeling : Metode Alternatif Dengan Partial Least Square. Semarang: Badan Penerbit Universitas Diponegoro. 
Greenberg, Jerald, Robert Baron. 2003. Behavior in Organizations (understanding and managing the human side of work ). Eight edition, Prentice Hall

Hackman, J.R \& Oldham, G.R. 1980. Work Redesign. Reading, Mass : Addison-Wesley

Handaru, Agung Wahyu, Shalahudin Abdillah dan Agung AWS Waspodo. 2013. Pengaruh Karakteristik Pekerjaan dan Kompensasi terhadap Komitmen Organisasi pada Pt "X" Jakarta. Jurnal Riset Manajemen Sains Indonesia (JRMSI) . Vol . 4, No. 2. Hal $238-256$

Hazem S. Kassem danAhmed M. Sarhan. 2013. Effect of job characteristics on satisfaction and performance: A test in Egyptian agricultural extension system. African Journal of Agricultural Research 8 (48): 6126-6130

Herzberg, F. 1966. Work and the nature of man. Cleveland, OH: World Publishing Company Janseen

ICA. 2006. Annual Report 2006. Geneva: International Co-operative Alliance (http://www.coop.org/statistics.html.)

Lestari, Maharani Ika, Sugiharto Toto.2007. Kinerja Bank Devisa dan Bank Non Devisa Dan Faktor-Faktor Yang Memengaruhinya. Proceeding PESAT (Psikologi,Ekonomi, Sastra, Arsitek \& Sipil) Auditorium Kampus Gunadarma, 21-22 Agustus ISSN : 1858 - 2559 Vol. 2. hal. 196

Luthans, Feed. 2006. Perilaku Organisasi edisi 10. Yogyakarta : Penerbit Andi.

Maharjan, Sarita. 2012.Association between Work Motivation and Job Satisfaction of College Teachers Administrative and Management Review Vol. 24, No 2, pp..45-55.

Mathis, Robert L. dan John H. Jackson. (2006). Manajemen Sumber Daya Manusia. edisi 10.Thomson SouthWestern

Meyer, J. 2003. Organizational Commitment and Job Performance : Its the nature of the commitment that counts. Journal of Applied Psychology, Vol 74 : 187-192.

McShane, S.L \& Von Glinow, M.A., 2008. Organizational Behavior: Emerging Realities For The Workplace Revolution, 4th Edition,

Nimalathasan. 2009. Profitabilityof listed pharmaceutical companies in Bangladesh. Economic and Administrative Series, No. 3 pp. 139-148

Noe, Hollenbeck, Gerhart, Wright (2010). Human Resource Management, Gaining Competitive Advantage $3^{\text {rd }}$ Edition . McGraw-Hill.

Rivai Vehitzal danJauvani Sagala. 2009. Manajemen Sumber Daya Manusia untuk Perusahaan Dari Teori ke Praktik. Jakarta : PT Rajagrafindo Persada

Robbins, Judge. 2007. Perilaku Organisasi, Buku 1 dan 2. Jakarta : Salemba Empat

Robbins, Stephen P.-Timothy A. Judge. 2008. Perilaku Organisasi. Edisi 2- Buku 1.Jakarta. Salemba Empat.

Simamora, Henry. 2004. Manajemen Sumber Daya Manusia. Edisi Ketiga Cetakan Pertama. Yogyakarta. Bagian Penerbitan STIE YKPN.

Subyantoro, Arief. 2009. Karaktristik individu, karakteristik pekerjaan, karakteristik organisasi dan kepuasan kerja pengurus yang dimediasi oleh motivasi kerja (Studi pada pengurus KUD di Kabupaten Sleman). Jurnal Vol 11 No 1.

Tamalero Yunita, Bambang Swasto, Djamhur Hamid. (2012). Pengaruh Karakteristik Pekerjaan dan kepuasan Kerja Terhadap Komitmen Organisasi dan Intention To Quit ( Studi Pada Karyawan PT. Manado Media Grafika). Jurnal Ilmu Administrasi Universitas Brawijaya. Vol 6 No 2

Tobing Diana Sulianti K. L. 2009. Pengaruh Komitmen Organisasional dan Kepuasan Kerja Terhadap Kinerja Karyawan PT. Perkebunan Nusantara III di Sumatera Utara Jurnal Manajemen Dan Kewirausahaan, VOL 11, NO 1, Maret.pp. 31-37

Tomsilav Hernaus \& Josip Mikulic. 2013. Work Characteristics and Work Performance of Knowledge Workers: What Goes Hand In Hand?. Working Paper Series. Paper No 13-09 University of Zagreb

Yusniar, Lubis. 2012. Pengaruh Karakteristik Individu, Karakteristik Pekerjaan, Iklim Organisasi terhadap Kepuasan dan Kinerja Karyawan. Jurnal Ekonomi dan Bisnis. vol 2 No 5. 